\title{
3 Latin American earnings inequality in the long run
}

\author{
4 Leticia Arroyo Abad ${ }^{1}$ Pablo Astorga Junquera ${ }^{2}$ (D)
}

5 Received: 11 May 2016/Accepted: 10 October 2016

6 (C) Springer-Verlag Berlin Heidelberg 2016

7 Abstract This paper traces between-group earnings inequality for six Latin 8 American countries over two centuries based on wage and income series compiled 9 from a large array of primary and secondary sources. We find that inequality varied 10 substantially by country and by period, questioning the notion that constant secular 11 inequality persistence is largely dominated by colonial legacies. There is a broader 12 inequality trajectory over the long run in the form of an " $\mathrm{m}$ " pattern with peaks 13 around 1880 and the 1990s and a trough around 1920/1930s. Export-led growth 14 does not necessarily imply a rise in inequality, while the import-substitution 15 industrialisation efforts did not translate into a more egalitarian distribution of 16 income. More notably, Latin America's experience does not exhibit the great 17 inequality levelling as seen in the North Atlantic economies from the 1930s to the 18 1970s.

Keywords Economic history · Economic development · Income inequality · Latin America

We are grateful to Peter Lindert and Jeffrey Williamson for comments, and to Marcelo de Paiva Abreu, Florencia Aráoz, Ame Bergés, Eduardo M. Cuesta, Raymundo Campos Vázquez, Amílcar Challú, José Díaz, Ewout Frankema, Aurora Gómez Galvarriato, María Gómez León, Michael Huberman, María López Uribe, Gerardo Lucas, Oscar Nupia, Mario Matus, Brian McBeth, Marco Palacios, Eustáquio Reis, Javier Rodriguez Weber, Carmen A. Romero, Héctor Valecillos, Henry Willebald, and Alan Wittrup for kindly providing wage data and ideas.

A7 $\square$ Leticia Arroyo Abad

A8 larroyoabad@middlebury.edu

A9 $\square$ Pablo Astorga Junquera

A10 pastorga@ibei.org

A11 1 Middlebury College, Middlebury, USA

A12 2 Institut Barcelona d'Estudis Internacionals, IBEI, Barcelona, Spain

\begin{tabular}{|l|llll|}
\hline & Journal : Small-ext 11698 & Dispatch : & $\mathbf{3 1 - 1 0 - 2 0 1 6}$ & Pages : 26 \\
Article No. : $\mathbf{1 5 0}$ & $\square$ LE & $\square$ & TYPESET \\
& MS Code : CLIO-D-16-00023 & $\square$ CP & $\square$ DISK \\
\hline
\end{tabular}


JEL Classification N36 - O15 - O54 · J31

\section{Introduction}

Latin America has always been tagged as "different" due to its unusually high inequality and, more recently, for its remarkable path towards more equality (López Calva and Lustig 2010; Gasparini et al. 2011). From an historical perspective, two views dominate the discussion of Latin America inequality. Led by Engerman and Sokoloff (1997) and Acemoglu et al. (2001), one view claims that the persistence of extractive institutions resulted in lower economic development outcomes and high inequality in the region since colonial times. In contrast, Williamson (2010), Arroyo Abad (2013a), and Astorga (2015a, 2016) argue that inequality was far from constant in the region, especially since the nineteenth century, highlighting the role of factor endowments, institutional changes, and the integration in world markets.

This paper presents a new set of consistent long-term estimates of pre-fisc earnings ${ }^{1}$ and wage inequality for up to six Latin American countries: Argentina, Brazil, Chile, Colombia, Mexico, and Venezuela (hereafter "LA-6"). ${ }^{2}$ It is the first attempt to provide series spanning two centuries using a consistent methodology. We find that during these two centuries, inequality fluctuated considerably by country and by period. This finding challenges the long-held view that colonial legacies largely dominated the evolution of inequality. Searching for a common trajectory, Latin America displayed, on average, an " $\mathrm{m}$ " pattern with peaks in the 1880s and the 1980s/1990s. While the changes were sizable during the nineteenth century, the following century offers a much more volatile trajectory. Unlike many developed countries, the region did not experience a sustained levelling of inequality in the 1940 s to the 1970 s. The sizable changes in inequality reflect the diversity in these economies in terms of factor endowments, integration in the world economy, and institutional adaptations resulting from changing domestic and international conditions.

The net impact of these factors on inequality is ambiguous and needs empirical investigation. For instance, the standard Heckscher-Ohlin model predicts that opening to trade in resource-abundant economies with concentrated resource ownership will worsen inequality, whereas the combination of advances in education and technology has the potential to move inequality either way. According to the Kuznets-Lewis process, industrialisation initially worsens and subsequently improves inequality as the labour force reallocates from agriculture to industry. And more integrated and wage-based labour markets should reduce earnings disparities.

Recent multi-country scholarship has focused on long-term inequality in the region. Williamson $(1999,2002)$ teased out developments in inequality by

\footnotetext{
1 Although our measures largely rely on wage data to estimate inequality, we also make allowances for non-labour income, especially during the twentieth century.

2 These countries have accounted for about three-quarters of the population over the last two centuries and thus are representative of the inequality in the region as a whole.
}

\begin{tabular}{|l|llll|}
\hline & Journal : Small-ext 11698 & Dispatch : $\mathbf{3 1 - 1 0 - 2 0 1 6}$ & Pages : 26 \\
Article No. : 150 & $\square$ LE & $\square$ TYPESET \\
MS Code : CLIO-D-16-00023 & $\square \quad C P$ & $\square$ & DISK \\
\hline
\end{tabular}


calculating ratios of GDP per capita to unskilled wages in the pre-WW2 period for a set of periphery countries (including Argentina, Brazil, Colombia, Cuba, Mexico, and Uruguay). Based on Williamson (2002) and household-survey Ginis, Prados de la Escosura (2007) constructed pseudo Ginis over the last century for Argentina, Brazil, Chile, Colombia, and Uruguay. Bértola et al. (2010) estimated Gini benchmarks for Brazil, Chile, and Uruguay around 1870 and 1920. Frankema (2010, 2012) studied the patterns of labour income shares in Argentina, Brazil, and Mexico during the twentieth century, and examined long-run industrial wage inequality in Argentina, Brazil, and Chile. Willebald $(2011,2015)$ looked at agrarian inequality in benchmark years for Argentina, Chile, and Uruguay. At a country level, Bértola (2005) for Uruguay (1870-2000) and Rodríguez Weber (2014) for Chile (1850-2009) offer valuable contributions. However, these studies only provide a partial picture of long-term trends and concentrate on selected countries or on labour income.

Some of these limitations are addressed by FitzGerald (2008) who computes a consistent set of yearly earnings Ginis based on four occupational groups with changing shares in the labour force in Argentina, Brazil, Chile, Colombia, and Mexico. However, one important shortcoming of these Ginis is that they rely on sectoral series of output per economically active person to estimate earnings levels. This implies well-functioning markets which is a strong assumption for a developing region, particularly before the first half of the last century. In this paper, we adopt FitzGerald's approach but calculate earnings Ginis using a newly assembled wage dataset compiled from a large array of primary and secondary sources. ${ }^{3}$ These data are supplemented with land rents to wage ratios-mostly until the early twentieth century. We look at inequality trajectories using the periodisation traditionally used in Latin American economic history (e.g., Bulmer-Thomas 2013; Hofman 2000). ${ }^{4}$

\section{Methodology}

To capture developments in inequality, we calculate historical between-group Gini coefficients based on estimates of earnings for four occupational groups, as in FitzGerald (2008). ${ }^{5}$ For each country the economically active population (EAP) is divided into four groups: Group 1 (employers, managers, and professionals), Group 2 (technicians and administrators), Group 3 (semi-skilled blue collars workers, other

\footnotetext{
3 Because the focus of this paper is inequality, we do not discuss real wage performance.

4 The periods are as follows: post-independence and the first globalisation wave (1830s-1910s); the stateled industrialisation period (ISI) under protection (1920s-1970s); and the second wave of export-led growth that started with a move towards trade liberalisation and market-friendly reforms-in some countries starting in the 1970s (1970s-2010).

5 This method is akin to the construction of dynamic social tables (combining benchmark years from census data with annual data on income from other sources) used for Uruguay (Bértola 2005), Chile (Rodríguez Weber 2014), and pre-industrial societies (Milanovic et al. 2010; Lindert and Williamson 1982).
}

Springer

\begin{tabular}{lllll} 
Journal : Small-ext 11698 & Dispatch : & $\mathbf{3 1 - 1 0 - 2 0 1 6}$ & \multicolumn{2}{l}{ Pages : 26 } \\
Article No. $: \quad \mathbf{1 5 0}$ & $\square \quad$ LE & & $\square$ & TYPESET \\
MS Code : CLIO-D-16-00023 & $\square$ & CP & $\square$ & DISK \\
\hline
\end{tabular}


urban workers in relatively low-productivity sectors such as retailing and transport, and artisans), and Group 4 (rural workers and personal services-including domestic servants-plus unskilled urban workers, and street vendors). To ensure consistency with the overall EAP series, the labour force in Group 3 is calculated as a residual.

The small number of groups reflects data limitations during most of the period covered, especially on income. In Group 1 owners of capital and landlords are included with managers and professionals. This group is dominated by non-wage income, including property income along with compensation for highly skilled and managerial labour. Group 2 includes a mix of manual and clerical workers with comparable years of formal education. Group 3 lumps together urban informal workers with precarious incomes and skilled artisans with relatively secure employment. Finally, Group 4 comprises unskilled rural workers and workers in personal services largely in urban areas.

Income inequality across the four groups captures differences in education and skills, and in property ownership. The main factors likely to affect earnings differences within our groups are geography and job dispersion (also reflecting gender and race/ethnic discrimination). Spatial income dispersion within countries was particularly important before the middle decades of the twentieth century when labour markets were not well integrated, allowing for inter-regional differences in earnings for equivalent jobs. This is likely to be a key factor contributing to high within-group inequality at a country level, but with a limited effect on betweengroup inequality, to the extent that wage differentials were similar across regions. ${ }^{6}$ Changes in gender pay rates are likely to have played a major role only late in the twentieth century, when female labour force participation accelerated in the LA-6 and Latin America in general (Camou and Maubrigades 2016). By contrast, the contribution of race discrimination to within-group inequality probably remained stable during most of the period, boosting earnings dispersion for relatively unskilled occupations (our Group 4). ${ }^{7}$ Since data constraints prevent our estimating within-group inequality, this paper therefore deals primarily with earnings dispersion between occupational groups.

\subsection{Historical between-group Ginis}

To measure earnings inequality we calculate a between-group Gini coefficient $($ GiniB) as follows:

\footnotetext{
${ }^{6}$ For instance, our estimations using data on rural wages in a sample of 15 states in Brazil (IBGE, 1924) show that whilst the regional dispersion (measured by the coefficient of variation) of wages for unskilled rural labourers dropped from 0.81 in 1911 to 0.40 in 1921 , and that for carpenters from 0.57 to 0.37 , the regional dispersion in the wage gap of the two occupations (reflecting between-group regional dispersion) only moved from 0.31 in 1911 to 0.37 in 1921 .

7 According to Brazilian census data, the proportion of the black population that completed primary school was below 5\% in 1940, 1950 and 1960, rising to $10 \%$ in 1980 and above $30 \%$ by 2000. In addition, black workers were predominately in low skills occupations in agriculture (Bucciferro 2016).
}

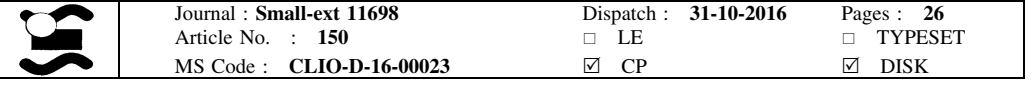




$$
G i n i B=\sum_{i=2}^{4} \sum_{j=1}^{i-1} e_{i} e_{j}\left|r_{i}-r_{j}\right|
$$

where $e_{i}$ is the EAP share of group $i$ and $r_{i}$ is the ratio of the mean income of group $i$ to that for the EAP as a whole (i.e., income per person engaged). The income share of each group $\left(s_{i}\right)$ is obtained as $r_{i} \times e_{i}$. Note that the EAP shares change over time as they are based on the size of occupational groups not on fixed percentages of the labour force. Therefore, this is a departure from a more standard Gini calculated with quartiles. ${ }^{8}$ Another aspect to bear in mind is that our income estimates exclude net taxes and the impact of social spending and do not account for differences in dependency ratios by income group. Thus, the definition of our Gini does not match the more familiar household income Gini, which is usually based on disposable income or household extended income.

Ideally, between-group inequality estimates should make allowances for the subsistence economy. ${ }^{9}$ However, there is little systematic and consistent evidence of the size of the subsistence economy (particularly important in the nineteenth century and early decades of the twentieth century), which could be used to make an adjustment (Berg 1970). To the extent that the population in the subsistence sector is included in the population census, we are assigning them an income equal to the unskilled wage. Also difficult to obtain for most of the period are differences in employment levels across occupational groups. Our income calculation in each category assumes full-time pay rates and that unemployment was affecting all categories equally.

For the nineteenth century we calculate a wage Gini, GiniB4w from (1) using available wage data for the four categories in five countries (Argentina, Chile, Colombia, Mexico, and Venezuela, or "LA-5"). The mean income for each category is calculated as a simple average of wage series. The outcome of this measure of wage inequality is largely driven by developments in the wage structure (i.e., wage compression or expansion) in the shorter to medium term. For the top group, our main limitation is lack of information on property income. For this century, however, we can complement the analysis of GiniB4w with available estimates for the ratio of the land rental rate to the average wage (rent-wage ratio) for Argentina, Chile, Mexico, and Venezuela (see "Appendix" for sources). This measure of relative factor prices suggests movements in the income ratios between landowners and wage earners. A rise (decline) in the ratio points to a disequalising (equalising) change in income inequality. To the extent that both the GiniB4w and the rent-wage ratio show reinforcing trends, the former may be a reasonable proxy for a more comprehensive between-group Gini including property income.

\footnotetext{
${ }^{8}$ It is likely that most of the potential differences between our occupational Gini and a hypothetical Gini based on quartiles over the whole distribution will cancel out. To illustrate the point, suppose that Group 4 accounts for $50 \%$ of the EAP, Group 2 for $25 \%$, Group 3 for $15 \%$, and Group 1 for $10 \%$. Compared with a quartiles Gini, our Gini is based on a less convex Lorenz curve for the first half of the distribution (resulting in lower inequality), a similar curve for the third $25 \%$, and a more convex Lorenz curve for the upper section of the distribution (resulting in higher inequality).

9 A non-monetary economy that relies on hunting, gathering, and agriculture to provide for basic needs.
}

Springer

\begin{tabular}{lllll} 
Journal : Small-ext 11698 & Dispatch : & $\mathbf{3 1 - 1 0 - 2 0 1 6}$ & \multicolumn{2}{l}{ Pages : 26 } \\
Article No. $: \quad \mathbf{1 5 0}$ & $\square \quad$ LE & $\square \quad$ TYPESET \\
MS Code : CLIO-D-16-00023 & $\square \quad C P$ & $\square$ & DISK \\
\hline
\end{tabular}


For the twentieth century the greater availability of better-quality estimates of overall national income, particularly with national accounts since the 1940s, makes it possible to include a gross estimation of property income. We also add Brazil into the analysis. The earnings Gini coefficients post 1900 (GiniB4) are obtained using (1), but now the income share for Group $1\left(s_{1}\right)$ is calculated as a residual by subtracting the income shares for the other three groups. This is then divided by the corresponding proportion of the EAP to yield Group 1's relative income level:

$$
r_{1}=s_{1} / e_{1}=\left\{1-\sum_{i=2}^{4} e_{i} r_{i}\right\} / e_{1} ; \text { with } \sum_{i=1}^{4} e_{i} r_{i}=1
$$

The income of the residual Group 1 is likely to capture property income for all the EAP and natural resource rents, together with earnings from highly paid workers. ${ }^{10}$ Its complement can also be a proxy for the labour income share. Calculated as a residual, the income for the top group may be subject to a significant margin of error. However, this method is likely to generate better estimates in Latin America than calculations based on tax data (famously unreliable for gauging income at the top, if available at all) and on household surveys (which are only available for the later decades and tend to miss information on top earners). ${ }^{11}$ To estimate mean earnings of the remaining three occupational groups, we rely, as in calculations for the nineteenth century, on wage series assembled to reflect differences in skills. ${ }^{12}$

There is a potential bias when estimating earnings of the top group according to (2). Since the average wage is taken as a proxy for average earnings of the three lower income groups (without discriminating between the employed and the unemployed in each group's EAP), at times of high unemployment, our series will overestimate $r_{2}, r_{3}, r_{4}$ and underestimate $r_{1}$ (as this is calculated as a residual) and thus underestimate inequality. ${ }^{13}$ This problem can be especially relevant during the

10 The long-term evidence in developed economies (Piketty 2014) shows that income from property tends to be concentrated in the top group, which means that our understatement of property income of the middle and bottom groups is small.

11 Alvaredo (2010) calculates the top 1\% income share for Argentina (1932-1972 and 2002) using tax data. Rodríguez Weber (2015) offers an estimation of the top 1\% income for Chile (1913-1973) based on dynamic social tables. In both cases, secular patterns are roughly in line with those shown by our $s_{1}$ for both countries. Astorga (2015a) offers evidence showing that, in general, our estimates for the mean income of Group 1 in the first half of the 20th century are consistent with data available on top earners; and that our calculated $s_{1}$ is also broadly consistent with available official estimates of property income shares for the second half of that century.

12 We are not accounting for fringe payments. According to the ILO's October Inquiry, in Chile (1953-59) they represented, on average, about $16 \%$ of total earnings for construction workers and in Venezuela about $20 \%$ in 1981 . The evidence available for the 1950 s and 1960 s indicates that fringe benefits only have a limited effect on skill differentials (Berg 1968).

13 Suppose total income $=200$; EAP $=100$ with full employment; so that average income per person engaged $=2$. The mean incomes are: Group $1=9$; Group $2=3$; Group $3=1.5$; Group $4=0.4$. The EAP shares are: $e_{1}=0.1, e_{2}=0.2, e_{3}=0.2, e_{4}=0.5$. Based on these data, $r_{1}=4.5(=9 / 2), r_{2}=1.5$, $r_{3}=0.75, r_{4}=0.2$; and GiniB4 according to $(1)=0.565$. Now suppose overall unemployment of $5 \%$ (affecting all groups equally); no data on Group 1' mean income; and no change in the mean income of the remaining three groups. The new income per person engaged is $1.9(=190 / 100)$. In this case, $r_{2}=1.58$ $(=3 / 1.9), r_{3}=0.79, r_{4}=0.21$. Then calculate $r_{1}=4.21$ as a residual using (2). The Gini now falls to 0.547 , when it should not.

\begin{tabular}{|l|lllll|}
\hline & Journal : Small-ext 11698 & Dispatch : $\mathbf{3 1 - 1 0 - 2 0 1 6}$ & Pages : 26 \\
Article No. : 150 & $\square$ LE & & $\square$ TYPESET \\
& MS Code : CLIO-D-16-00023 & $\nabla$ & CP & $\nabla$ & DISK \\
\hline
\end{tabular}


early years of the Great Depression or during the outbreak of the Debt Crisis in the 1980s. In order to minimise the potential impact of this bias, we calculate deviations of the unemployment rate (when available) from an assumed long-term rate (as a proxy for the natural rate of unemployment) and then adjust our overall income per person engaged series accordingly. In this way, overall income per person engaged is adjusted upwards during period of unusually high unemployment (minimising a potential underestimation of Group 1's income) and vice versa at times of unusually low unemployment. ${ }^{14}$

\subsection{Comparability and comparisons}

To sum up, to estimate inequality over the two centuries, we construct two betweengroup Ginis based on four occupational categories: GiniB4w and GiniB4. They differ in the estimation method of the top-group income. The former uses data on wages for highly skilled professionals, whereas the latter makes allowances for property income. Therefore, these Ginis are not necessarily comparable in levels, but they can inform us about trends. In order to have a measure which is defined consistently across both centuries, we construct using (1) a narrower between-group Gini, GiniB3w, based on the three lower occupational groups dominated by labour income.

Besides, when studying the twentieth century, comparing GiniB4 and GiniB3w makes it possible to identify the relative contribution of wage inequality to the outcome of the more encompassing inequality measure provided by GiniB4. This is of interest because forces affecting labour and property income are different. The former is driven by demand and supply conditions in the labour market, as well as by institutional factors such as minimum wage legislation or unionisation. Property income is primarily driven by savings and investment behaviour, inheritance laws, and the rate of return to wealth. ${ }^{15}$ The extent to which GiniB4 and GiniB3w show similar trends depends on developments in the top income share. For instance, narrowing wage inequality (reflecting wage compression) and a falling top income share will result in a narrowing of overall inequality. But if wage inequality and the top income share move in opposite directions, the inequality trajectory as measured by GiniB4 may not match that of wage inequality.

Our Ginis offer a clear improvement over more basic measures commonly used to track historical inequality such as the Williamson ratio and the skilled wage premium. The former has important limitations to capture a more complex distributional picture in the region during most of the twentieth century, whereas the latter leaves aside valuable information about the semi-skilled workers and on changes in the labour force. Our evidence for the LA- 6 in the twentieth century

14 We perform such an adjustment in all six countries from around 1970 onwards based on official unemployment rates, and during the 1930s using estimates available for Chile, Mexico, and Venezuela (in Argentina, Brazil, and Colombia, we apply the same adjustment as in Mexico). Otherwise we assume that unemployment is at its natural rate. For additional details, see Astorga (2015a).

15 These structural differences are reflected in a relatively low average correlation between both measures (0.4) in the LA-6 over the twentieth century. The paired correlations are calculated using a fiveyear panel data, so as to minimise distortions caused by interpolation. 
indicates that changes in the GiniB3w are largely in tune with those in the skilled wage premium (an average paired correlation of 0.77 ), whereas the link is weaker with the Williamson ratio $(0.60)$.

\section{A new history of earnings inequality since 1830}

Latin America's inequality trajectory since the early nineteenth century is dominated by volatility and diversity amid important structural and institutional transformations. Despite the common colonial past, inequality in each economy did not follow similar secular trends. To study inequality in our sample of countries, we divide the discussion by three periods loosely defined to capture the transitions into and out of the global economy: 1830s-1910s, 1920s-1970s, and 1970s-2010. During the second period, the region moved towards a more modern, urbanised, and industrially diverse manufacturing and service economy.

The explanations for trend diversity and commonality are to be found in the fundamentals linked to the action of market forces, institutional change, and the political economy of distribution. Providing a detailed and rigorous account of such forces and their impact on inequality is beyond the scope of this paper. However, as we discuss our evidence, we highlight key factors that are likely to have played an important role in a given epoch.

\subsection{Post-independence and the first globalisation wave (1830s-1910s)}

To trace the likely impact of institutional change, commodity market swings, immigration, and the expansion of the land frontier, we focus on the four-group Gini $($ GiniB4w) as a measure of wage inequality (GiniB3w behaves similarly) and use land rent-wage ratios to capture the relative performance of the landowning class relative to the average worker. These ratios are only available for Argentina, Chile, Mexico, and Venezuela before World War I (see Fig. 1). ${ }^{16}$

Latin America integrated into the world economy as a supplier of raw materials, specialising in a handful of commodities. ${ }^{17}$ High export concentration magnified macro and distributional volatility in response to terms of trade fluctuations. ${ }^{18}$ This was also a period of transition to a modern capitalist economy and the development of a mobile and wage-based labour force (Bértola and Ocampo 2012). Thus, limited labour mobility and coercion in some cases may have reduced the benefits received

${ }^{16}$ Table 1 in the Appendix also offers average annual rates of growth of terms of trade as well as weighted-average real wages by country in selected periods.

17 The main commodities for the countries in our sample were as follows: Argentina (wool, beef, and wheat), Chile (nitrates and copper), Colombia (coffee and gold), Mexico (silver and copper), and Venezuela (coffee and cacao). In many cases the two most important commodities represented at least 50\% of total exports (Arroyo Abad 2013a; Bulmer-Thomas 2013).

${ }^{18}$ In theory, improved terms of trade should benefit the factor used intensively in the production of the exportable good (e.g., land), and, assuming concentrated ownership, it should increase inequality. But the impact on the wage structure is complex depending on the relative skill intensity of the tradable and nontradable sectors (Galiani et al. 2010).

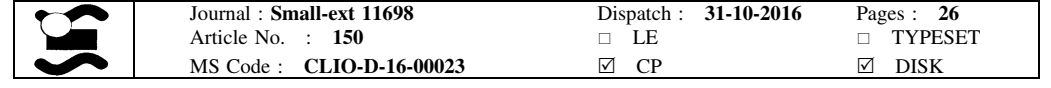


by unskilled labour from the expansion in foreign demand. To illustrate the impact of this transition into the world economy, we will examine first the role of foreign demand followed by the changes in factor endowments.

In all the countries, we find booms and busts. Argentina in the 1850s and 1860s offers an example of the inequality implications of the commodity cycle. With an unprecedented increase in the international demand of wool, the price of exports rose by over 50\% from 1840 to 1860 (Sábato 1990; Newland 1998). This boom had disequalising effects as shown by the rise of the land rental to average wage index in Fig. 1 .

Venezuela also enjoyed an export boom in this period. With the decimation of the cacao trees during the independence wars within its territory, coffee gained ground in the export sector. Especially with a more stable economy after the Federal War (1859-1863), coffee cultivation expanded towards the Andean region (Brito Figueroa 1973, 2002; Yarrington 1997). As a result, the rise in terms of trade in the 1870 s drove an increase in the land rental to wage index peaking in mid-1870s. In Mexico, the terms of trade fell by about $50 \%$ in the last decades of the nineteenth century from its peak in the mid-1880s, and inequality roughly followed that trend.

Changes in the relative scarcity of factor endowments were also linked to the expansion of the export sector. In particular, migration inflows from Europe were sizable in Argentina and Uruguay. In Argentina, wage inequality shows a slight increase until the early 1880 s and a significant compression in the 1890 s as the result of the recession induced by the Barings crisis in 1890. The uptick in migration inflows in the $1880 \mathrm{~s}$ contributed to the increase of inequality, as unskilled labour became more abundant relative to land. ${ }^{19}$ Inequality experienced an equalizing trend until the 1890 s as the immigrant inflow contributed to all skill levels. $^{20}$

After the War of the Pacific against Bolivia and Peru (1879-1883), Chile was able to expand its natural resource frontier to include large deposits of nitrates. This new pillar of economic activity in Chile attracted unskilled workers. As documented by Rodríguez Weber (2014), the drop in inequality (see GiniB4w and the rentunskilled wage ratio ${ }^{21}$ in Fig. 1) during the first global century in Chile reflects a decline in property income driven by the crisis of the 1870 s and the mineral frontier

19 On average, the net migration during the $1880 \mathrm{~s}$ was around $2.2 \%$ of the total population per year. In comparison the prior and subsequent decades, the rates were $1.2 \%$ and $0.9 \%$, respectively (Departamento General de Inmigración 1895, 1914). This rise in inequality driven by immigration (measured through the land rent-wage ratio) is also consistent with the experience of Uruguay as documented by Bértola and Williamson (2006) and Arroyo Abad (2013a). Arroyo Abad (2013a) estimates that population would have been $48.2 \%$ smaller in 1900 in the absence of migration.

${ }^{20}$ While around $40 \%$ of the foreigners' occupations were as day workers and agricultural workers, the rest worked in a wide array of semi-skilled occupations such as masons, smiths and machinists (Comisión Directiva del Censo 1898). For an analysis on the integration of the Italians and Spaniards in the Buenos Aires labour market, see Arroyo Abad and Sánchez-Alonso (2015).

21 Yet, while all these indicators point to an overall drop of inequality during the period, it appears that the landowning class enjoyed better income trends than the average wage earner (see rent/average wage ratio in Fig. 1).

\begin{tabular}{|l|llll|}
\hline & Journal : Small-ext 11698 & Dispatch : $\mathbf{3 1 - 1 0 - 2 0 1 6}$ & Pages : 26 \\
Article No. : $\mathbf{1 5 0}$ & $\square$ LE & $\square$ & TYPESET \\
& MS Code : CLIO-D-16-00023 & $\square$ CP & $\square$ & DISK \\
\hline
\end{tabular}



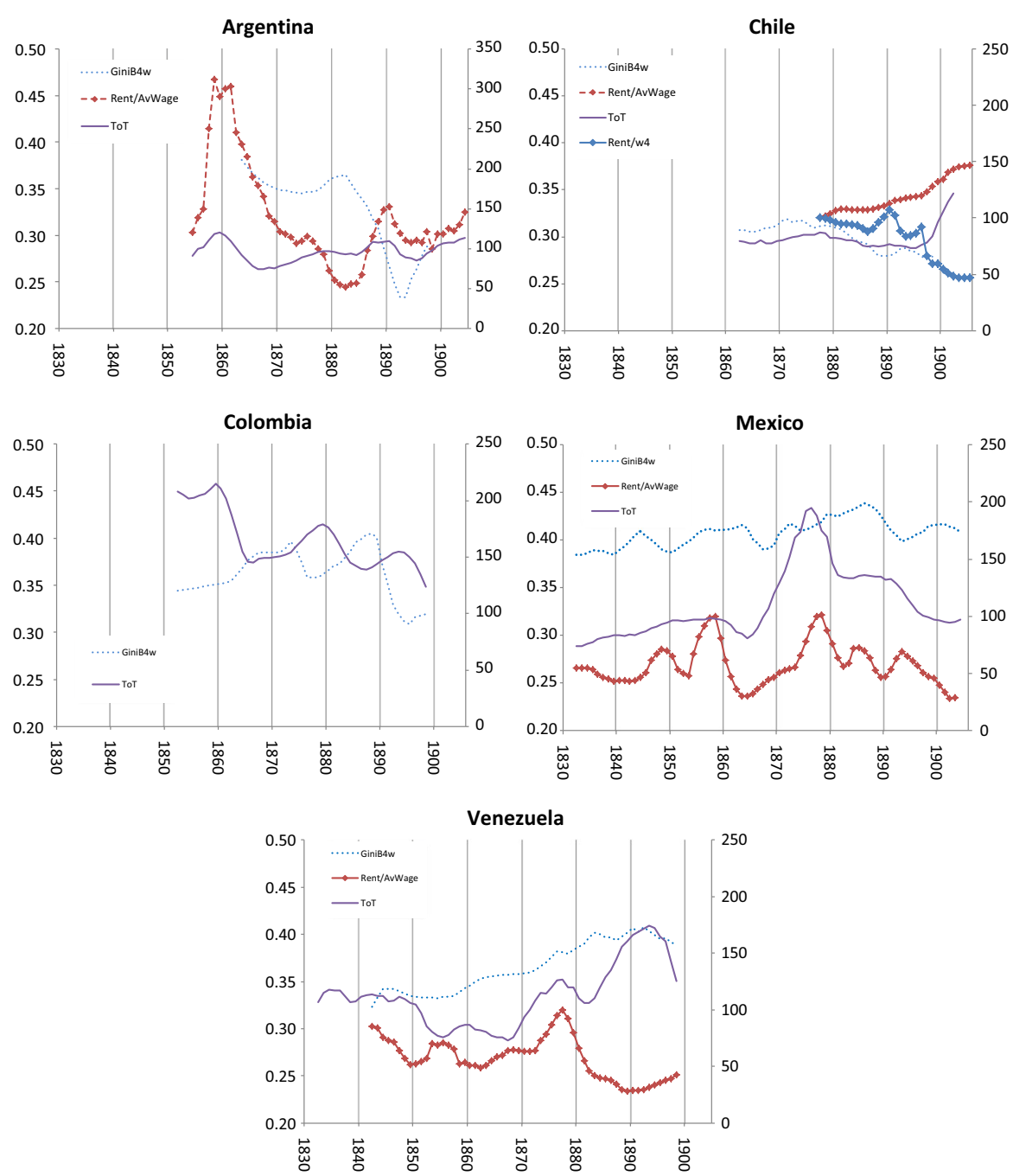

Fig. 1 Wage Ginis, land rent-wage ratios, and the Terms of Trade in the nineteenth Century. Left axis GiniB $4 \mathrm{w}=$ inequality among four occupational groups, 5-year centred average. Right axis rent/wage ratio $=$ index of (annual land rent per hectare/average wage rate), $1880=100$ ) and ToT $=$ terms of trade, $1900=100,5$-year centred averages. Sources see "Appendix"; GiniB4w for Chile (1862-1900): Rodríguez Weber (2014)

expansion. The crisis of 1870s reduced the elite's relative share given the drop of the price of gold and wheat during the decade. ${ }^{22}$

In Colombia, the last decades of the nineteenth century also brought about modernisation as coffee gained ground and joined gold as the main commodity exports. This development translated into capital inflow to finance infrastructure. In

22FL01 ${ }^{22}$ In addition, educational expansion also changed the relative scarcity of skilled to unskilled labour 22FL02 (Rodríguez Weber 2014).

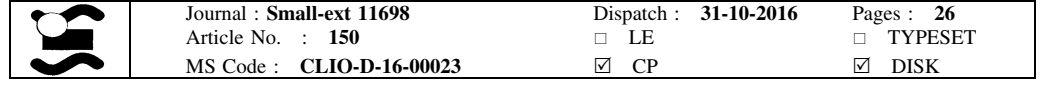


addition, it also prompted the emergence of a small rural middle class, a departure from the reigning latifundia system. With the expansion of the export sector, a domestic manufacturing sector also emerged (Sevilla Soler 1992). Until the 1880s, wage inequality $($ GiniB $4 w)$ rose, while the export sector was expanding.

Latin American long transition into the world economy presents a heterogeneous inequality picture deeply intertwined with commodity cycles. In good times, inequality (as measured by the land rent to wage ratio) increased as in the case of Argentina in the 1860s and Venezuela in the 1870s. With busts, inequality improved as exemplified in Mexico in the 1880s. Yet, this integration also prompted changes in factor endowments such as frontier expansion and mass migration like in Argentina. In some cases, the expansion of the export sector also promoted reallocation in the domestic economy leading to a decline in wage inequality such as in Colombia and in Chile.

\subsection{Transition and import-substituting industrialisation (1920s-1970s)}

In response to the external shocks brought about by the World Wars and the Great Depression, many countries in the region underwent major economic adjustments and revised their growth strategies. By the 1930s, many economies turned more protectionist (via tariffs or the use of multiple exchange rates) to promote domestic manufacturing (Thorp 1998). This move gave way to an explicit strategy of importsubstituting industrialisation led by the state (ISI) that dominated economic policy from 1940 to 1970 . These policies together with rapid urbanisation (particularly in Brazil, Colombia, Mexico, and Venezuela) ${ }^{23}$ had a potentially disequalising impact as implied by the Kuznets-Lewis process. ${ }^{24}$

As shown in Fig. 2, the interwar years are a turning point from lower to higher earnings inequality in Brazil, Colombia, Mexico, and Venezuela. In Argentina and Chile the change in trend occurs later in the 1950s. Developments in the terms of trade, and the export sector in general, continued to have an important distributional impact. A shared commodity cycle (a boom in the 1920s and a bust in the 1930s) offers a good opportunity to examine the degree of commonality in the inequality responses by countries and measures. The association with wage inequality is clearer. First, rising trends in all six countries (only in the second half in Colombia) in the 1920s boom; then, inequality declines during the 1930s bust (Mexico being the exception)_-indicating falling skill premiums.

However, trajectories in earnings inequality (GiniB4) do not always confirm those in wage inequality (GiniB3w), pointing to a more complex distributional picture across countries once the contribution of the top-group income share is

23 The urbanisation rates in the 1920s and the 1970s were, respectively, 38 and $81 \%$ in Argentina, 15 and $62 \%$ in Brazil, 38 and $79 \%$ in Chile, 15 and 61\% in Colombia; 15 and 63\% in Mexico, 24 and $76 \%$ in Venezuela (Astorga et al. 2005).

24 Although our wage data cannot fully reflect the urban-rural divide, the conditional correlation between GiniB3w and the labour productivity gap between agriculture and manufacturing in the LA-6-after controlling for other key variables such as terms of trade and factor endowments-is significant and positive during the period 1935-2011. However, a similar econometric exercise using GiniB4 lacks

24FL05 significance (Astorga 2015b). 


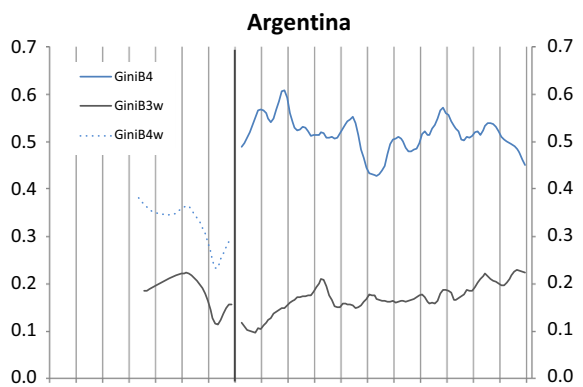

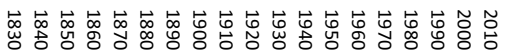
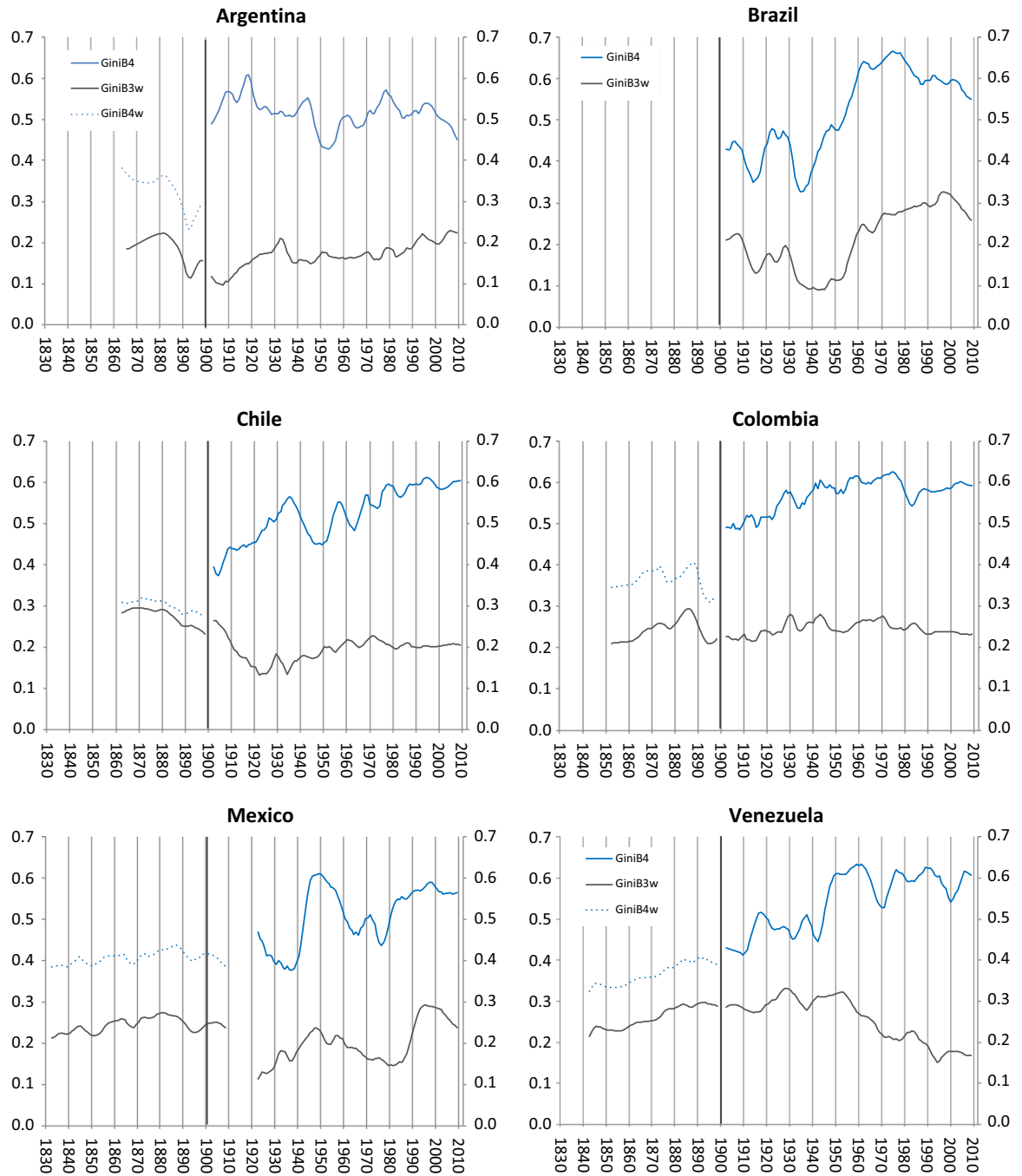

Fig. 2 Earnings inequality in six countries, 1830-2010. (Gini coefficients; 5-year moving averages). Because of data limitations GiniB4 and GiniB3w in Colombia between 1900 and 1905 are set equal to the 1906-1907 average. Series for the twentieth century are a revised version of those in Astorga (2016). Sources see "Appendix"; GiniB4w for Chile (1862-1900): Rodríguez Weber (2014)

included. ${ }^{25}$ Argentina, Venezuela, and Mexico display contrasting trends. In the first two countries, wage expansion during the 1920s was at least partially offset by falling top-group income shares (as reflected in a stable or falling GiniB4), while wage compression in the 1930s was accompanied by rising top shares (a stable or rising GiniB4). In post-revolutionary Mexico, earnings inequality narrowed and

$\overline{25}$ Although we cannot rule out that some of these differences may reflect estimation shortcomings and data limitations.

\begin{tabular}{|l|lllll}
\hline & Journal : Small-ext 11698 & Dispatch : $\mathbf{3 1 - 1 0 - 2 0 1 6}$ & \multicolumn{2}{c|}{ Pages : 26 } \\
Article No. : 150 & $\square \quad$ LE & $\square$ & TYPESET \\
& MS Code : CLIO-D-16-00023 & $\square$ & $\square P$ & $\square$ & DISK \\
\hline
\end{tabular}


wage inequality widened over the two decades. ${ }^{26}$ In Brazil GiniB4 and GiniB3w moved broadly in tune, but with important fluctuations. ${ }^{27}$ First, inequality widened until late 1920s with a commodity boom boosting property income and skilled wages; and then it fell in the 1930s. Chile and Colombia display matching rising trends in the 1920s, but contrasting moves in the 1930s.

During ISI, especially in the 1950s and the 1960s, the dominant trend was rising earnings inequality. It widened in Argentina (after a trough around 1950), Brazil, Chile, Colombia, and Venezuela (up to the early 1960s) driven by a growing income share of the top group, ${ }^{28}$ but narrowed in Mexico $^{29}$ (in all cases amid a sustained rise in real wages). Some peaks in earnings inequality are associated with specific events. In Mexico, the spike around 1950 is linked with the surge of business opportunities in the country (amid subdued wages) created by the war effort in the US. The rapid inequality widening in Venezuela in the 1950s likely reflects a doubling in oil production with a $25 \%$ rise in oil prices until 1957 during the Suez Crisis (Baptista 1997) boosting property income.

Trajectories in wage inequality were more diverse: roughly constant in Argentina; widening in Brazil (after the mid-1940s), Chile and Colombia (post 1950); and narrowing in Mexico and Venezuela (in both cases post 1950). This diversity is the result of competing forces-associated with structural change and labour institutions-with mixed distributive results. On the one hand, the acceleration of urbanisation and industrialisation generated downward pressures on unskilled wages (of increasingly urban workers), while relative skills scarcity boosted skill premiums (which translated in a rise in GiniB3w). ${ }^{30}$ On the other hand, governments and unions supporting wage austerity subdued upward trends in most countries during the 1940s-especially during the war years (Roxborough 1984), while the introduction of minimum wage legislation and pro-labour policies (particularly in Argentina and Mexico) supported rising trends in 366 unskilled wages and wage compression during the 1950s and 1960s (Méndez 1950).

26FL01

26 The 1917 Constitution set new minimum wage levels as well as profit sharing. Higher real wages and higher living standards emerged as priorities for the government after the revolution Bortz (2005).

${ }^{27}$ GiniB4 for Brazil shows a relatively low level until the early 1930s. At this time, according to the 1920 population census, about $80 \%$ of the labour force was rural, illiterate, and low skilled (Bértola et al. 2009). Under such circumstances, it is likely that the maximum feasible income Gini was relatively low reflecting the fact that poorer societies have a smaller surplus for the elite to extract (Milanovic et al. 2010).

${ }^{28}$ This could reflect increased profits of firms operating under protection. However, the relationship between ISI and property income is complex and requires further research. In general, the combination of industrialisation with a decline in agriculture generated winners (the new industrialists) as well as losers (the traditional landlords). Also the state became a key economic actor via state-owned enterprises. See Rodríguez Weber (2015) for the analysis of Chile.

${ }^{29}$ Favourable minimum wages policies and high rates of unionisation in Mexico contributed to a long spell of wage compression in this period (Márquez Padilla 1981).

${ }^{30}$ Intra-industry wage inequality also rose in Argentina (from early 1960s), Brazil, and Chile (Frankema 2012) suggesting skill-biased technological change.

\begin{tabular}{|l|llll|}
\hline & Journal : Small-ext 11698 & Dispatch : $\mathbf{3 1 - 1 0 - 2 0 1 6}$ & Pages : 26 \\
Article No. : 150 & $\square$ LE & $\square$ & TYPESET \\
& MS Code : CLIO-D-16-00023 & $\square$ CP & $\square$ DISK \\
\hline
\end{tabular}


In the last decades of the twentieth century (1970-2000), Latin America implemented neoliberal structural reforms and shifted from relatively closed, state-dominated economies, to ones more open and market oriented. The reforms were expected to deliver sustained economic growth, raise productivity, generate jobs (especially in the formal economy), and alleviate poverty. However, in reality, they produced meagre results in terms of improving living standards. Income inequality rose moderately from already high levels. This was partly the result of trade liberalisation which encouraged the expansion of skill-intensive export activities. In a context of relatively short skills supply, this resulted in widening skill premiums (Stallings and Peres 2000). ${ }^{31}$

Our evidence broadly reflects the general story told by the household Ginis. Rising trends in earnings inequality was the norm, except in Brazil where it stayed roughly unchanged after peaking around 1980. This was also accompanied by widening wage inequality particularly in Argentina, Brazil, and Mexico after the 1982 Debt Crisis. The 1970s oil boom resulted in wage compression in Venezuela and Mexico driven by relative gains for unskilled labour. But this equalising move proved to be ephemeral in Mexico. And, although it continued in Venezuela in the following two decades, this time round it was driven by a drastic fall in skilled wages. This secular decline in wage inequality and in the labour income share in Venezuela responds to a combination of a sustained fall in physical capital accumulation and a rise in human capital accumulation. Both factors boosted returns to capital and reduced the skill premium (Rodríguez 2000). ${ }^{32}$

Institutional and demographic changes also played their part in explaining the move towards worsening in inequality. The military regimes in Argentina (1976-1983), Chile (1973-1990), and Brazil (1963-1980) effectively restricted—or banned-the action of unions, increased flexibility in the labour market, and reduced the coverage of the minimum wage as part of the reform agenda (Morley 2000). More generally, unionisation plummeted across the region averaging only $10.7 \%$ of the workforce by 2005 compared to a peak of $23 \%$ in the 1970s (Roberts 2012). ECLAC (2015) shows a $5.9 \%$ decline in the average real minimum wage for the LA-6 during the 1980s, followed by a moderate recovery of $1.7 \%$ annual increase in the $1990 \mathrm{~s}$.

The delayed impact on the labour force of high population growth rates in the 1950s and 1960s (Argentina is the exception), together with increasing participations rates - particularly female rates—also undermined the unskilled wages. ${ }^{33}$ The

\footnotetext{
31 In a panel data study, Székely and Sámano (2012) found that greater trade openness was associated with widening income inequality in the region during the period 1980-2000. They also found that, once fully implemented, trade liberalisation did not lead to further inequality rises in the first decade of this century.

32 The average skilled wage (Group 2) in Venezuela fell by an annual rate of $-2.4 \%$ in the 1980 s and 1990 s, after rising by $2.1 \%$ in the 1970 s. The same calculation for the average unskilled wage shows a fall of $-2.1 \%$ after a $1.9 \%$ rise.

33 According to our calculations based on official figures, the population in the LA-6 (simple averages) grew 74\% between 1950 and 1970, and 56\% between 1970 and 1990. The corresponding growth rates for the EAP are $64 \%$ and $85 \%$. The same calculations for the $1930-1950$ period shows a more even process with population and EAP growth both at $57 \%$. As to female participation rates, there were few changes in 1940-1970, and an explosive growth in participation from 1970 to 2000 (Camou and Maubrigades 2016).
}

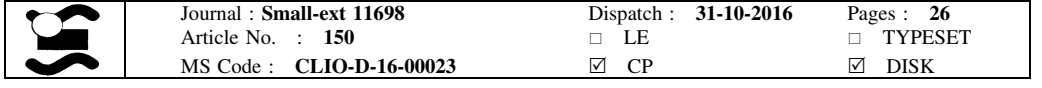


effect of these underlying trends in the labour market was compounded by a wave of deregulation and privatisations that shifted formal employment to an already large informal sector (PREALC 1990).

The inauguration of the twenty-first century brought about a Chinese-driven commodity boom, which made possible improvements in employment and real wages - in particular for the unskilled, amid a fall in wage premiums. Governments across the region-largely of left-wing orientation-implemented more progressive social spending (which equalising effects are largely missing in our pre-fisc Ginis). They also engaged in a more active role in the labour market, raising the minimum wage or taking a more pro-union stance (Gasparini and Lustig 2011). Our inequality measures fall in Argentina, Brazil and Mexico, an outcome consistent with trends in labour earnings Ginis calculated from household surveys (World Bank 2012). In Chile and Colombia, they remain roughly stable and show an erratic behaviour in Venezuela.

\subsection{An average inequality trajectory}

Is it possible to unveil a common inequality pattern for Latin America? To construct a regional account for inequality, we present four Ginis as simple country averages. A visual inspection of the averages reveals a secular process resembling an " $\mathrm{m}$ "shaped curve for 1865-2011 with peaks in the 1880s and 1980s/1990s ${ }^{34}$ The trough is around 1920 for wage inequality (GiniB3w), in the 1930s for earnings inequality (GiniB4), and in the 1950s for inequality in the Southern Cone (GiniB4_SC). Broadly speaking, this evidence suggests rising inequality until the 1880s and then a decline until the 1920s-1930s. Next, rising inequality dominated the industrialisation period (1940s-1960s) driven by the experience of the late industrialisers (Brazil, Colombia, and Venezuela). In the Southern Cone, the upward trend started in the mid-1950s. Inequality reached a plateau in all three Ginis at the time of the implementation of the structural reforms; then, it narrowed during the first decade of the twenty-first century.

The broad periodisation of inequality implied by the m-shaped schedule invites different interpretations. A first narrative is related to changes in labour market institutions. During the second half of the nineteenth century, the labour market experienced limited integration and selective coercion depending on the relative scarcity of labour. Later, with more market integration, minimum wage legislation, and other pro-labour policies, inequality decreased. Starting in the 1970s, more flexible markets and labour informality drove inequality upwards. ${ }^{35}$

Transitions in and out of the global economy offer a second interpretation. For the first global century, the evidence is mixed with rising and falling trends of aggregate inequality with no clear association between the first episode of exportled growth and inequality. The middle period displayed protection associated with

\footnotetext{
34 A population-weighted average (where developments in Brazil and Mexico have a larger weight) produces a similar-though more pronounced—shape but with a peak around 1980.

35 These three periods also match contrasting developments in real wages. The LA- 6 real wage grew at average annual rates of $0.7 \%$ in $1870-1915,2.2 \%$ in $1940-1980$, and $0.7 \%$ in $1980-2011$ (see Table 1).
} 
Latin America

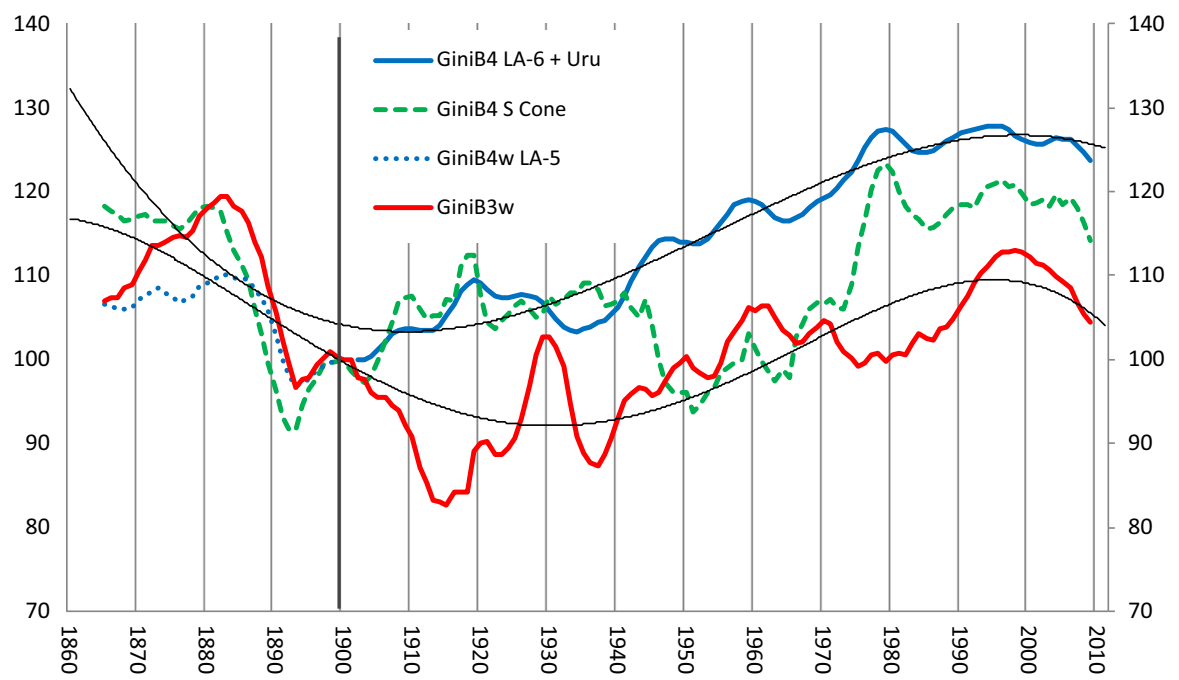

Fig. 3 Multi-country average earnings inequality, 1860s-2010. (indices, $1900=100$; 5-year moving averages). Notes GiniB4 LA-6 + Uru is the earnings Gini for LA-6 plus Uruguay; GiniB4 S Cone is the earnings Gini for the Southern Cone countries (Argentina, Chile, and Uruguay) from 1900, complemented by the wage GiniB4w in 1865-1900; GiniB4w LA-5 is the wage Gini for LA-5, and GiniB3w is the wage Gini for the bottom three categories. The 1911-21 averages exclude Mexico. Sources see "Appendix"; Uruguay: Bértola (2005)

lower inequality in the Southern Cone, but with widening inequality in the other countries. These mixed results point at country differences in resource endowments and in the implementation of the ISI itself (e.g., oil-rich Venezuela with limited import substitution). The second export-led period is clearly associated with widening inequality up to the 2000 , but with a turnaround during the first decade of the 21 st century. ${ }^{36}$ Thirdly, the Kuznets-Lewis narrative would predict widening inequality during the industrialisation decades and levelling off towards the end. This is broadly consistent with the trajectories of GiniB4 and GiniB3w in Fig. 3, with less support from the Southern Cone.

\section{Conclusions}

This paper offers a long-run view of Latin American inequality based on new estimates from an extensive array of primary and secondary sources. This is the first study to estimate earnings inequality for the nineteenth and twentieth centuries for

36 The lack of a clear link between inequality and the trade cycle does not necessarily invalidate the six Latin American countries using a consistent methodology. The use of betweenendowments. But, changing inequality trends within a period dominated by either openness or closeness complicates a simple interpretation based on this model.

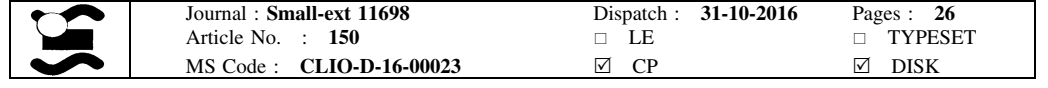


group inequality Ginis advances our knowledge over other proxies used in previous studies.

Our methodology and sources have limitations, and we hope that future research will result in better indicators. Our estimates cannot fully capture income disparities throughout the income distribution, especially within groups and at the top. As a result the estimates can inform about trends but are less useful for level comparisons. With the inclusion of four occupational groups, we offer more nuanced estimates; however, we cannot offer insights on rural-urban inequality.

Transitions in and out of the global economy and the interplay of international conditions and adaptations of domestic institutions gave rise to sizable inequality changes in these two centuries. Despite country and period diversity, on average, there is a shared inequality pattern in the long run in the form of an " $\mathrm{m}$ " shape with peaks around the 1880s and the 1990s, and a trough in the 1920s-1930s. This secular pattern is robust to a split of the sample between the Southern Cone and the rest, although the trough shifts to the 1950s for the Southern Cone. Heterogeneous experience and volatility question the notion of constant secular inequality persistence largely determined by colonial legacies.

The diversity within Latin America shows that export-led growth does not necessarily imply a rise in inequality. During the first globalisation wave, some booms increased inequality but crises decreased inequality as well. These findings challenge previous claims stating that trade openness increased inequality during the first globalisation wave (Bértola and Ocampo 2012; Prados de la Escosura 2007; Williamson 2010). Our findings also reveal a mixed inequality pattern during the ISI decades in line with Bértola and Ocampo (2012)'s insights. A more protectionist approach then did not translate into more equality in all cases. Inequality in Argentina and Chile improved until the 1950s but deteriorated in the rest of the countries. With the exhaustion of the ISI strategy in the 1970s, inequality was on the rise in most countries reaching a plateau in the last decades of the twentieth century amid the implementation of the structural reforms.

The emerging chronology suggested by the " $\mathrm{m}$ " curve for the LA-6 (plus Uruguay) does not exhibit the great inequality levelling as experienced by the North Atlantic economies from the 1940s to the 1970s (Atkinson 2008; Piketty 2014). In Latin America, the shared reversal of inequality only came in the twenty-first century driven by a natural resource export-led growth, lower skill premiums, and more progressive social policies. However, with the reversal of the commodity cycle this equalising tide may be retreating once again.

\section{Appendix}

Notes on estimation methodolgy and data sources. Selected data series can be downloaded from the Global Prices and Income History Group website (Tables 1, 2). 


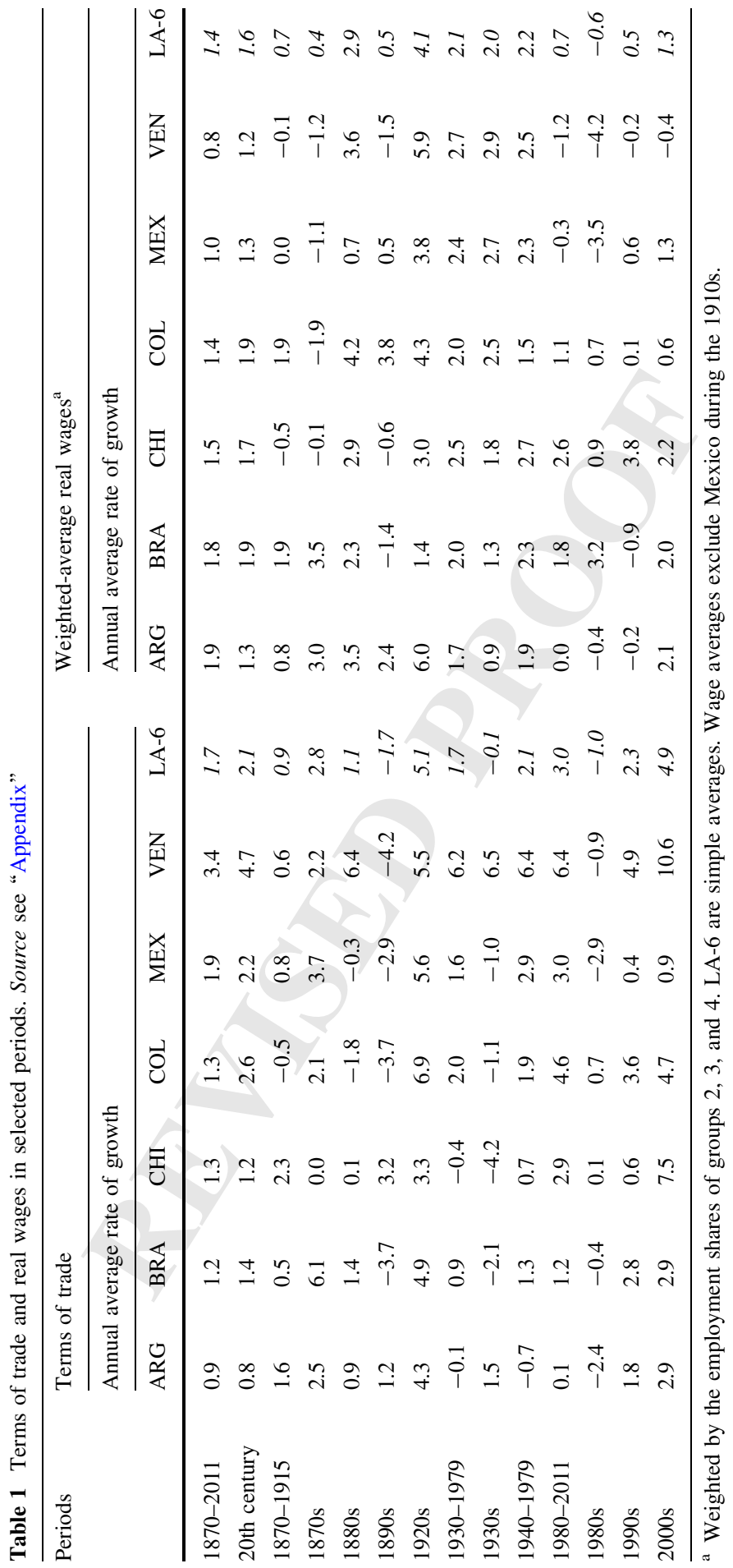


Table 2 Representative occupations by group

\begin{tabular}{|c|c|c|c|c|}
\hline Country & Group 1 & Group 2 & Group 3 & Group 4 \\
\hline Argentina & $\begin{array}{l}\text { Accountant/ } \\
\text { engineer/doctor }\end{array}$ & $\begin{array}{l}\text { Scribe/ } \\
\text { administrative } \\
\text { clerk/archivist }\end{array}$ & $\begin{array}{l}\text { Carpenter, smith, bricklayer, } \\
\text { semi-skilled factory worker }\end{array}$ & $\begin{array}{l}\text { Urban servant } \\
\text { and rural day } \\
\text { worker }\end{array}$ \\
\hline Chile & $\begin{array}{l}\text { Accountant/ } \\
\text { engineer }\end{array}$ & $\begin{array}{l}\text { Administrative } \\
\text { clerk }\end{array}$ & Construction worker/artisan & $\begin{array}{l}\text { Urban servant } \\
\text { and rural day } \\
\text { worker }\end{array}$ \\
\hline Colombia & $\begin{array}{l}\text { Accountant/ } \\
\text { engineer/doctor }\end{array}$ & $\begin{array}{l}\text { Scribe/ } \\
\text { administrative } \\
\text { clerk }\end{array}$ & Mason and carpenter & $\begin{array}{l}\text { Urban servant } \\
\text { and rural day } \\
\text { worker }\end{array}$ \\
\hline Mexico & $\begin{array}{l}\text { Accountant/ } \\
\text { engineer/doctor }\end{array}$ & $\begin{array}{l}\text { Scribe/ } \\
\text { administrative } \\
\text { clerk }\end{array}$ & Mason & $\begin{array}{l}\text { Urban servant } \\
\text { and rural day } \\
\text { worker }\end{array}$ \\
\hline Venezuela & Accountant/doctor & Scribe/archivist & $\begin{array}{l}\text { Carpenter/stoker/lower rank } \\
\text { officer }\end{array}$ & $\begin{array}{l}\text { Urban servant } \\
\text { and rural day } \\
\text { worker }\end{array}$ \\
\hline
\end{tabular}

\section{Nineteenth century}

- Employment shares

In general terms, we used the occupation classification available in census when available. Each occupation was classified according to ECLAC 9-category list and then further summarised in 4 groups: Group 1 (employers, managers, and professionals), Group 2 (technicians and administrators), Group 3 (urban workers), and Group 4 (rural workers and personal services including lowskilled urban workers and street vendors) following the methodology by Astorga (2015). As census data are not available for many Latin American countries during this period, we used other estimations as detailed below.

Argentina: From 1869 to 1900, we used the 1869 and 1895 census with direct interpolation for the intervening years.

Chile: We used the censuses of $1865,1875,1895$, and 1905 to estimate the shares.

Colombia: Unfortunately for Colombia, there are no data on occupations until the twentieth century. We used Venezuela's shares.

Mexico: We assumed stable shares based on the 1895 Census.

Venezuela: The shares are estimated using the social tables by Brito Figueroa (2002).

- Population and terms of trade

Argentina, Mexico, and Venezuela: Arroyo Abad (2013a).

Brazil: IBGE website.

Chile: EH ClioLab.

Colombia: Meisel and Ramirez (2007).

\begin{tabular}{|l|llll|}
\hline & Journal : Small-ext 11698 & Dispatch : $\mathbf{3 1 - 1 0 - 2 0 1 6}$ & Pages : 26 \\
& Article No. : $\mathbf{1 5 0}$ & $\square \quad$ LE & $\square$ & TYPESET \\
& MS Code : CLIO-D-16-00023 & $\square$ CP & $\square$ & DISK \\
\hline
\end{tabular}


- Wages

Argentina: Rural wages are for day workers with board from Cortés Conde (1979), Sábato (1990), Cuesta (2012), and Gelman and Santilli (2014) for the provinces of Buenos Aires, Entre Ríos, and Santa Fe. Unskilled urban wages correspond to servants from Barba (1999) and Arroyo Abad (2013a) for Buenos Aires. Semi-skilled data came from an array of sources: Carrasco (1886), Buchanan (1898), Patroni (1897), Cortés Conde (1979), and Barba (1999). Skilled wages were compiled from Dirección General de Estadística (1894), the National Archives (Archivo General de la Nación de Argentina 1820-1900), national and provincial budgets, railroad and other public utilities budgets (Congreso de la Nación 1860-1900; Ketzelman and Souza 1930; Barba 1999).

Brazil: Wages in Rio de Janeiro from Lobo (1978). For unskilled wages, we used series of labourers of a small plot to produce fruit and vegetables (hortelão) and porters (porteros). For semi-skilled wages are an average wage for masons and carpenters. For skilled workers, we used wages for clecks (escriturario)-only available post 1890.

Chile: Wages are from Rodríguez Weber (2014) and Matus (2012).

Colombia: Wages are from Urrutia and Arrubla (1970) and Meisel and Ramirez (2007). For rural agricultural workers, wages refer to dayworkers as reported in Meisel and Ramirez (2007) and from Acevedo Echeverri et al. (1989). The daily wages are annualized assuming 235 working days per year. 38

For blue-collar workers we used the category servant or construction worker (obrero de la construcción) from Urrutia and Arrubla (1970). For skilled and semi-skilled workers, we compiled data from national budgets (Leyes de los Estados Unidos de Colombia 1830-1900).

Mexico: Wages are from the Mexican National Archives (Archivo General de la Nación and Archivo Histórico del Instituto Nacional de Antropología e Historia, Hospitales), the Mexico City Archive (Archivo Histórico del Distrito Federal, Empleados and Beneficencia Pública del Distrito Federal), several national budgets, and Challú and Gomez-Galvarriato (2015). For rural wages, we used a variety of estimates from several sources including Bazant (1975) and Semo (1988), and all estimates include corn rations priced at market value from most of Mexican regions. For late nineteenth century, we used the minimum wage for the agricultural sector (de México 1965). ${ }^{40}$ For high skilled and semi-skilled workers, the data are from the Mexico City National Archives and national budgets (Ministerio de Hacienda y Crédito Público 1881-1892; Arrillaga 1830-1900; Cámara de Diputados 1820-1900). These

\footnotetext{
38 Workers were granted one free day a week, typically Sundays, in addition to the numerous religious holidays celebrated throughout the year (González Pérez 2012). Note that Urrutia and Arrubla (1970) assume 360 working days per year.

40 The dataset is part of an ongoing project on Mexican inequality in the long run by L. Arroyo Abad, A. Challú and A. Gómez Galvarriato.
}

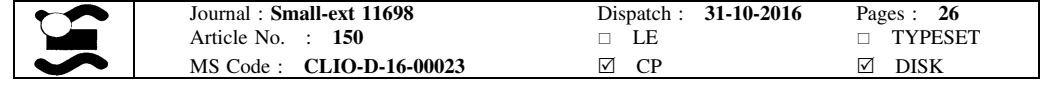


budgets provide wages by state in some occupational categories; the data collected were mainly from state capital cities, covering around $90 \%$ of the population.

Venezuela: Wages for skilled, semi-skilled and urban unskilled occupations are from the National Archives (Archivo General de la Nación de Venezuela). For rural wages, several sources show that the average monetary wage was 2 reales per day. Both urban servants and rural workers received in-kind rations (Lucas 1991; Yarrington 1997; Cartay 1988). No source indicates with precision the ration composition; however, a couple of sources provide rough estimations of around 1.5 reales per day in 1830s (Archivo Arzobispal 1830-1900). ${ }^{42}$

Taking that figure into consideration, we assumed that the rural day workers and urban servants were provided corn and beans for a household subsistence

- Price deflators based on the basket and prices published by Arroyo Abad (2013b).

Argentina: Consumer Price Index (CPI) published by Ferreres (2005).

Brazil: Wholesale price index from Catão (1992).

Chile: ClioLab (2015) provides a CPI for the reference period.

Colombia: The deflator used is based on Meisel and Ramirez (2007)

Mexico: We used the respectable basket by Challú and Gomez-Galvarriato (2015).

Venezuela: We combined the CPI for Caracas (Arroyo Abad 2013b) with the GDP deflator (De Corso 2013).

- Land Rents: Arroyo Abad (2013a); Chile: Willebald (2015) estimated benchmarks for $1875,1885,1895$, and 1907 with interpolation for the intervening years.

\section{Twentieth century}

- Employment shares: see Astorga (2015a, Annex C).

- Terms of trade: Brazil from IBGE (2015) website, Chile from Díaz et al. (2005). Otherwise MOXLAD (2015) database.

- Wages

To assemble comparable and consistent wage series, we first set comparable wage levels in the core period of 1965-1980 and then proceed to complete the series back and forth by using rate of growth of a number of wage series from various sources. To set comparable levels across the LA-6, we do the following:

\footnotetext{
${ }^{42}$ For the late colonial period, Lana-Berasain (2014) notes that the cost of subsistence for slaves was 1.25 reales per person per day.
}

\begin{tabular}{|l|lllll|}
\hline & Journal : Small-ext 11698 & Dispatch : $\mathbf{3 1 - 1 0 - 2 0 1 6}$ & Pages : 26 \\
Article No. : 150 & $\square$ LE & $\square$ TYPESET \\
\hline
\end{tabular}


- For the unskilled workers circa 1970, we relied on comparable series of agricultural wages for unskilled workers in agriculture and the urban minimum wage from PREALC (1982) and ECLAC website.

- For semi-skilled workers, we used the average wage in most cases including seven occupations (bricklayers and masons, structural iron workers, concrete workers, carpenters and joiners, painters, plumbers, and electrical fitters) in the construction industry collected in ILO's (International Labour Organization 1936-1964, 1964-1982) October Enquiry, Part I.

- For relatively skilled workers, where possible, we used monthly wages for clerks (an average of bank tellers and accountants) available in ILO's (International Labour Organization 1936-1964, 1964-1982) October Enquiry, Part II, or average wages in manufacturing from PREALC (1982) otherwise.

- Finally, to have comparable wages in a single currency across countries we calculate PPP\$ values using the PPP exchange rates available for 1970 (ECLA 1978).

Regarding rate of growth: for Group 2, we use series of manufacturing wages and, when not available, wages in the public sector for relatively skilled employees such as mechanics or mid-range officers (e.g., Colombia). For Group 3, we generally use wage series in the construction sector or in other relatively low-skilled sectors such as retailing. For Argentina, we use average wages of non-agricultural sectors (excluding government) pre-1965. Chile pre-1930 uses wages in lowproductivity sectors (food and drinks and textiles). For Mexico, we used the changes in minimum wages for the early decades. For Group 4, pre-1965, when possible we compiled wages for unskilled rural and urban workers. In some cases, they are supplemented with wages for unskilled government employees (e.g., Colombia). And in the post-1980 period, we use a combination of rural and urban minimum wages, or relatively low-productivity sectors such as retailing and personal services. Figure A-5 in Astorga (2015a) shows the real wage series by the three occupational groups and the estimated income per person engaged series. We use the same deflator (usually the CPI) for both overall income per person engaged and wages, so that the inequality measures are equivalent to those calculated from nominal values. All series are updated up to September 2016. Full details on sources and methodology will be included in a forthcoming publication. Contact the author for more details.

- Price deflators: see sources and notes in Astorga (2012). In Argentina to avoid the under-reporting of CPI inflation by INDEC (2015) in 2006-11, we use a CPI index reported by seven provinces compiled by CENDA (2005-2011).

\section{References}

Acemoglu D, Johnson S, Robinson J (2001) The colonial origins of comparative development: an empirical investigation. Am Econ Rev 91(5):1369-1401

\begin{tabular}{|l|llll|}
\hline & Journal : Small-ext 11698 & Dispatch : $\mathbf{3 1 - 1 0 - 2 0 1 6}$ & Pages : 26 \\
& Article No. : 150 & $\square$ LE & $\square$ TYPESET \\
MS Code : CLIO-D-16-00023 & $\square$ CP & $\square$ & DISK \\
\hline
\end{tabular}


Alvaredo F (2010) The rich in Argentina over the twentieth century 1932-2004. Chapter 6. In: Atkinson A, Piketty T (eds) Top incomes vol. II: a global perspective. University Press Oxford, Oxford Archivo Arzobispal (1830-1900) Convento, Caracas

Archivo General de la Nación de Argentina (1820-1900) Sala IX: Documentos de Gobierno (Administrativos y militares), Periodo Nacional, Hospital de Hombres, Hospital de Mujeres, Ejército, Contaduría, Oficina de la Sociedad Filantrópica, Buenos Aires, Argentina

Archivo General de la Nación de Venezuela, Recopilación de Leyes y Decretos de Venezuela, (1830-1903), Caracas, Venezuela

Archivo Histórico del Distrito Federal, Empleados (1856-1877), Beneficencia Pública del Distrito Federal (1862-1900)

Archivo Histórico del Instituto Nacional de Antropología e Historia, Hospitales (1820-1860)

Arrillaga BJ (1830-1900) Recopilación De Leyes, Decretos, Bandos, Reglamentos, Circulares y Providencias de los Supremos Poderes y otras autoridades de la República Mexicana. Imprenta de J. M. Fernandez de Lara, México

Arroyo Abad L (2013a) Persistent inequality? Trade, factor endowments and inequality in Republican Latin America. J Econ Hist 73:38-78

Arroyo Abad L (2013b) Inestabilidad, costo de vida y salarios reales en Venezuela en el Siglo XIX. Am Lat Hist Econ 20:114-137

Arroyo Abad L, Sánchez-Alonso B (2015) A city of trades: Spanish and Italian immigrants in late nineteenth century Buenos Aires, Argentina. EHES working papers in Economic History 88

Astorga P (2012) Mean reversion in long-horizon real exchange rates: evidence from Latin America. J of Inter Money and Finance 31(6):1529-1550

Astorga P (2015a) Functional inequality in Latin America: news from the twentieth century. Discussion Papers in Economic and Social History, Universidad of Oxford, 135

Astorga P (2015b) Inequality and economic development in Latin America, 1900-2011. Paper presented at the EHES conference at Pisa, Italy, September 4-5

Astorga P (2016) Functional inequality in Latin America: news from the twentieth century. In: Bértola L, Williamson JG (eds) Has Latin American inequality changed direction? Looking over the long run. Springer, New York

Astorga P, Bergés AR, Fitzgerald EVK (2005) The standard of living in Latin America during the twentieth century. Econ Hist Rev 59(1):765-796

Atkinson A (2008) The changing distribution in OECD countries. Oxford University Press, Oxford

Baptista A (1997) Bases cuantitativas de la economía venezolana, 1830-1995. Ediciones Fundación Polar, Caracas

Barba FE (1999) Aproximación al estudio de precios y salarios en Buenos Aires desde fines del siglo XVII hasta 1860. Editorial de la Universidad Nacional de La Plata, La Plata

Bazant J (1975) Cinco haciendas mexicanas: tres siglos de vida rural en San Luis Potosí. El Colegio de México, Mexico

Berg EJ (1968) Wage structure in less developed countries. Center for Research on Economic Development. Discussion Paper 1. University of Michigan

Berg EJ (1970) Wages and employment in less developed countries. Center for Research on Economic Development. Discussion Paper 13. University of Michigan

Bértola L (2005) A 50 años de la curva de Kuznets: crecimiento y distribución del ingreso en Uruguay y otras economías de nuevo asentamiento desde 1870. Investigaciones en Historia Económica 3:135-176

Bértola L, Ocampo JA (2012) The economic development of Latin America since independence. Oxford University Press, Oxford

Bértola L, Williamson J (2006) Globalization in Latin America before 1940. In: Bulmer-Thomas V, Coatsworth JH, Cortes Conde R (eds) The Cambridge economic history of Latin America. Cambridge University Press, Cambridge

Bértola L, Castelnovo C, Willebald H (2009) Income distribution in Brazil 1870-1920. Paper presented at the conference "A comparative approach to inequality and development: Latin America and Europe", Instituto Figuerola, Universidad Carlos III, Madrid, May 8-9

Bértola L, Castelnovo C, Rodríguez Weber J, Willebald H (2010) Between the colonial heritage and the first globalization boom: on income inequality in the southern cone. Revista de Historia Económica 20(2):307-341

Bortz J (2005) Earning a living. A history of real wage studies in twentieth-century Mexico. Lat Am Res Rev 41(2):112-138

Springer

\begin{tabular}{|l|llll|}
\hline & Journal : Small-ext 11698 & Dispatch : $\mathbf{3 1 - 1 0 - 2 0 1 6}$ & Pages : 26 \\
Article No. : $\mathbf{1 5 0}$ & $\square$ LE & $\square$ & TYPESET \\
& MS Code : CLIO-D-16-00023 & $\square$ CP & $\square$ & DISK \\
\hline
\end{tabular}


Brito Figueroa F (1973) El problema tierra y esclavos en la historia de Venezuela. Ediciones Teoría y Praxis, Caracas

Brito Figueroa F (2002) Historia económica y social de Venezuela. Universidad Central de Venezuela, Caracas

Bucciferro JR (2016) Race and Brazilian inequality in the long run. In: Bértola L, Williamson JG (eds) Has Latin American inequality changed direction? Looking over the long run. Springer, New York

Buchanan W (1898) La moneda y la vida en la República Argentina. Revista de Derecho, Historia y Letras I (II)

Bulmer-Thomas V (2013) The economic history of Latin America since independence. Oxford University Press, Oxford

Cámara de Diputados (1820-1900) Diario de los Debates de la Cámara de Diputados del Congreso de los Estados Unidos Mexicanos. Imprenta de la Cámara de Diputados, México

Camou M, Maubrigades S (2016) The lingering face of gender inequality in Latin America. In: Bértola L, Williamson JG (eds) Has Latin American inequality changed direction? Looking over the long run. Springer, New York

Carrasco G (1886) Descripción Geográfica y Estadística de la Provincia de Santa Fe. Imp. Lit. y Encuad. De Stiller \& Laas, Buenos Aires

Cartay R (1988) Historia económica de Venezuela. Vadell Hermanos Editores, Caracas

Catão LAV (1992) A new wholesale price index for Brazil during the period 1870-1913. Revista Brasileira de Economia 46:519-533

Centro de Estudios para el Desarrollo Argentino (CENDA) (2005-2011) IPC en siete Provincias

Challú AE, Gomez-Galvarriato A (2015) Mexico's real wages in the age of Great Divergence. Rev Hist Econ 33:83-122

Comisión Directiva del Censo (1898) Segundo Censo de la República Argentina, 10 de mayo de 1895 Taller Tip. de la Penitenciaria nacional, Buenos Aires

Congreso de la Nación (1860-1900) Diario de Sesiones, 1860-1900. Compañía Sud-American de Billetes de Banco, Buenos Aires

Cortés Conde R (1979) El progreso Argentino, 1880-1914. Editorial Sudamericana, 1979, Buenos Aires

Cuesta EM (2012) Precios y salarios en Buenos Aires durante la gran expansión. Revista de Instituciones, Ideas y Mercados 56:159-179

De Corso G (2013) El crecimiento económico de Venezuela desde la oligarquía conservadora hasta la revolución bolivariana: 1830-2012. Una visión cuantitativa. Revista de Historia Económica 31(3):321-358

Departamento General de Inmigración, 1895, 1914 (1895) Memoria del año 1894, Buenos Aires

Departamento General de Inmigración, 1895 (1914). Memoria del año 1913, Buenos Aires

Díaz J, Lüders R, Wagner G (2005) Chile 1820-2000: La República en cifras. Santiago

Dirección General de Estadística (1894) Censo de los empleados administrativos, funcionarios judiciales personal docente: De la República Argentina correspondiente al 31 de diciembre de 1893. Compañía sud-americana de billetes de banco, Buenos Aires

Echeverri CA, Arango Echeverri R, Gaviria Rios M, Muñoz Valdez J (1989) Haciendas cafetaleras antioqueñas: relaciones técnicas y sociales. Lecturas de Economía 28:91-126

ECLA (1978) Series históricas del crecimiento de América Latina, Cuadernos Estadísticos de la CEPAL 3, Santiago de Chile

ECLAC (2015) CEPALSTAT|Bases de datos. http://interwp.cepal.org/sisgen/ConsultaIntegrada. asp?idIndicador=340\&idioma=e. Accessed 10 Oct 2015

EH ClioLab-Instituto Economía Pontificia Universidad Católica de Chile (2015). http://economia.uc.cl/ cliolab/. Accessed Oct 2015

El Colegio de México (1965) Estadísticas económicas del Porfiriato. Fuerza de trabajo y actividad económica por sectores. El Colegio de México, México

Engerman SL, Sokoloff KL (1997) Factor endowments, institutions, and differential paths of growth among New World economies: a view from economic historians of the United States. In: Haber S (ed) How Latin America fell behind. Stanford University Press, Stanford

Ferreres OJ (2005) Dos siglos de economía argentina, 1810-2004: Historia argentina en cifras. Editorial El Ateneo, Buenos Aires

FitzGerald VFK (2008) Economic development and fluctuations in earnings inequality in the very long run: the evidence from Latin America 1900-2000. J Int Dev 20:1028-1048

Frankema E (2010) Reconstructing labor income shares in Argentina, Brazil and Mexico 1870-2000. J Iber Lat Am Econ Hist 28(2):343-374

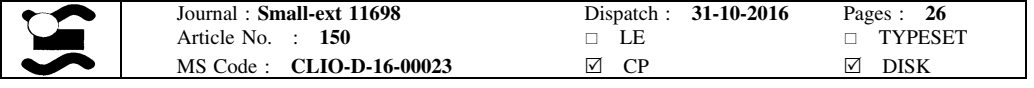


Frankema E (2012) Industrial wage inequality in Latin America in global perspective, 1900-2000. Stud Comp Int Dev 47:47-74

Galiani S Heymann D Magud N (2010) On the distributive effects of terms of trade shocks: the role of non-tradable goods. IMF working paper wp/10/241

Gasparini L, Lustig N (2011) The rise and fall of income inequality in Latin America. ECINEQ Working Paper 2011-213

Gasparini L, Cruces G, Tornarolli L (2011) Recent trends in income inequality in Latin America. Economía 10:147-201

Gelman J, Santilli D (2014) Los salarios y la desigualdad en Buenos Aires, 1810-1870. Amér Lat en la Hist econ 21:83-115

González Pérez M (2012) Ceremoniales y nación: un escenario. Ediciones Antropos, Bogotá

Hofman A (2000) The economic development of Latin America in the twentieth century. Cheltenham Instituto Brasileiro de Geografía e Estadística, IBGE (2015). http://www.ibge.gov.br/

Instituto Nacional de Estadística y Censos de la República Argentina, INDEC (2015). http://www.indec. mecon.ar/

International Labour Organization (1936-1964) International Labour Review. ILO Publications: Geneva International Labour Organization (1964-1982) Yearbook of Labour Statistics. ILO Publications: Geneva Ketzelman F, Souza RF (1930) Colección Completa De Leyes Del Estado Y Provincia De Buenos Aires Desde 1854 a 1929. Editorial "Lex", Buenos Aires

Lana-Berasain JM (2014) Añil, cacao y reses. Los negocios del indiano Esteban González de Linares en tiempos de mudanza. Memorias 22

Leyes de los Estados Unidos de Colombia (1830-1900). Imprenta de Gaitan, Bogotá

Lindert P, Williamson JG (1982) Revising England's social tables 1688-1812. Explor Econ Hist 19:308-402

Lobo EM (1978) História do Rio de Janeiro (do capital comercial ao industrial e financiero). IBMEC, Rio de Janeiro

López Calva LF, Lustig N (2010) Declining inequality in Latin America: a decade of progress?. United Nations Development Programme, New York

Lucas G (1991) Sueldos y salarios en Venezuela (1800-1936). Doctoral thesis, Universidad Católica Andrés Bello

Márquez Padilla C (1981) Nivel del salario y dispersión de la estructura salarial (1939-1977). Econ Mex 3:53-54

Matus M (2012) Crecimiento sin desarrollo: precios y salarios reales durante el ciclo salitrero en Chile (1880-1930). Editorial Universitaria, Santiago de Chile

Meisel A, Ramirez MT (2007) Economía colombiana del siglo XIX. FCE, Bogota

Méndez J (1950) Minimum wages in Latin America. Inter Labour Rev 62:116-140

Milanovic B, Lindert P, Williamson JG (2010) Pre-industrial inequality. Econ J 121:255-272

Ministerio de Hacienda y Crédito Público (1881-1892) Ley de ingresos y presupuesto de egresos del Tesoro Federal. Imprenta de I. Cumplido, Mexico

Montevideo-Oxford Latin American Economic History Database, MOXLAD (2015) The Latin American Centre, Oxford University, and the Universidad de la República (Uruguay). http://www.lac.ox.ac.uk/ moxlad-database

Morley SA (2000) The effects of growth and economic reform on income distribution in Latin America. CEPAL Rev 71:23-40

Newland C (1998) Exports and terms of trade in Argentina, 1811-1870. Bull Lat Am Res 17:409-416

Patroni A (1897) Los trabajadores en la Argentina. Buenos Aires. Imprenta Litografía y Ecuadernación

Piketty T (2014) Capital in the twenty-first century. Harvard University Press, Harvard

Prados de la Escosura L (2007) Inequality and poverty in Latin America: a long-run exploration. The new comparative economic history: essays in honor of Jeffrey G. Williamson, 291-315

PREALC (1982) Mercado de trabajo en cifras. 1950-1980. PREALC Publications, Lima

PREALC (1990) Empleo y Equidad. PREALC Publications, Lima

Roberts KM (2012) The politics of inequality and redistribution in Latin America's post-adjustment era. UNU-WIDER Working Paper 2012/8

Rodríguez F (2000) Factor shares and resource booms. Accounting for the evolution of Venezuelan inequality. UNU-WIDER Working Paper 205

Rodríguez Weber J (2014) La economía política de la desigualdad de ingreso en Chile. Doctoral thesis in economic history, Universidad de la República de Uruguay

\begin{tabular}{|l|llll|}
\hline & Journal : Small-ext 11698 & Dispatch : $\mathbf{3 1 - 1 0 - 2 0 1 6}$ & Pages : 26 \\
& Article No. : $\mathbf{1 5 0}$ & $\square \quad$ LE & $\square$ & TYPESET \\
& MS Code : CLIO-D-16-00023 & $\square$ CP & $\square$ & DISK \\
\hline
\end{tabular}


Rodríguez Weber $\mathbf{J}$ (2015). The political economy of the top $1 \%$ in an age of turbulence: Chile 1913-1973. Documentos de trabajo 41, facultad de ciencias sociales de la Universidad de la República

Roxborough I (1984) The urban working class and the labour movements in Latin America. In: Bethell L (ed) The Cambridge history of Latin America, vol 4. Cambridge University Press, Cambridge

Sábato H (1990) Agrarian capitalism and the world market: Buenos Aires in the pastoral age, 1840-1890. University of New Mexico Press, Albuquerque

Semo E (1988) Historia de la cuestión agraria mexicana. Siglo XXI, Mexico

Sevilla Soler R (1992) Capital y mercado interno en Colombia, 1880-1930. Anu Estud Am 49:585-599

Stallings B, Peres W (2000) Growth, employment, and equity: the impact of the economic reforms in Latin America and the Caribbean. ECLAC and Brookings Institution Press, Washington, DC

Székely M, Sámano C (2012) Did trade openness affect income distribution in Latin America? Evidence for the years 1980-2010. UNU-WIDER Working Paper 2012-3

Thorp R (1998) Progress, poverty and exclusion: an economic history of Latin America in the 20th Century. Inter-American Development Bank Publications, Washington, DC

Urrutia M, Arrubla M (1970) Compendio de estadísticas históricas de Colombia. Bogotá

Willebald H (2011) Natural resources, settler economies and economic development during the first globalization: land frontier expansion and institutional arrangements. Ph.D. dissertation. Universidad Carlos III, Madrid

Willebald H (2015) Patrones distributivos en las economías templadas de reciente asentamiento: desigualdad en el ingreso agrario durante la Primera Globalización (1870-1913). Hist Agrar 66:75-104

Williamson JG (1999) Real wage inequality and globalization in Latin America before 1940. Revista de Historia Económica XVII(special issue):101-142

Williamson JG (2002) Land, labor, and globalization in the Third World, 1870-1940. J Econ Hist 62(1):55-85

Williamson JG (2010) Five centuries of Latin American inequality. Rev Hist Econ 28:227-252

World Bank (2012) The labor market story behind Latin America's transformation. Washington, D.C Yarrington D (1997) A coffee frontier: land, society and politics in Duaca, Venezuela, 1830-1936. University of Pittsburgh Press, Pittsburgh

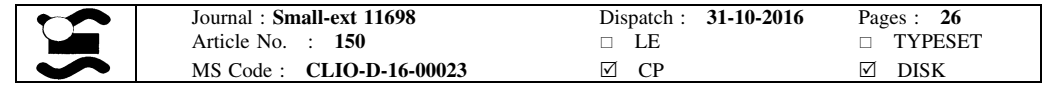

